\title{
KINGS WITHOUT A KINGDOM: THE RAJAS OF KHURDA AND THE JAGANNATHA CULT
}

HERMANN KULKE

In February 1877 Divyasimha Deva, Maharaja of Puri and hereditary Superintendent of the great Jagannatha temple in Puri, was convicted of murder of a sadhu and sentenced to transportation for life to the Andaman Islands. ${ }^{1}$ Only a few years later in 1882, however, various groups of Puri priests and Oriya Brahmins petitioned the British Government in support of the Puri royal family and against a proposal to take over the administration of the Jagannatha temple:

The Maharaja of Pooree is the most respectable person among the Hindoos of India. Though there are many wealthier Rajas in Hindoostan none of them is held by the Hindoos with equal veneration. ${ }^{2}$

It is perhaps not so astonishing that the pandas (priests) of Puri extolled the position of the Puri Rajas, even after a case of murder, since their own vested interests were involved. However, it is most surprising that it was this kind of agitation which forced the British Government of India to repeal its proposed Act XIV of 1882 and to grant a certificate to Rani Suryamani, mother of the convict, allowing her to administer the temple in the name of her minor grandson for nearly twenty years. The British government also conferred the titled of Raja on the minor son of the convict even during his father's lifetime. ${ }^{3}$ In 1887 the Government of India lost another case, the famous "Pooree Temple Case", 4 when it again tried to bring the temple administration under the supervision of a Government-controlled board. This victory was celebrated not only by local Oriya newspapers but also by the editor of the Statesman:

There can be no reasonable doubt that the administration of the temple and the charge of its property have from time immemorial been vested in the Rajah of Khurda who is supposed, for certain ceremonial purposes connected with the

As a member of the Orissa Research Project, financed by the German Research Council, I stayed in Orissa from Sept. 1970 to Sept. 1971 and from May to August 1974. My thanks are due to Prof. P. Mukherjee, Bhubaneswar, who kindly allowed me to quote from his unpublished book (n. 1); to Prof. Ashin Das Gupta, Shantiniketan; and to Prof. Dr Rothermund, Heidelberg.

1 P. Mukherjee, "History of the Jagannath Temple during the 19th Century" (MS. [to be published 1975 by Orient Longman, Delhi]) [hereafter op. cit.], pp. 477-80. Sad$h u$, a Hindu ascetic.
2 Jagannatha Temple Correspondence [hereafter JTC] Part VI, p. 1384, No. 3 of July 8, 1882, Mahadeo Panda and 450 others to Commissioner of Orissa, Cuttack. A similar petition was sent by the leaders of the Brahmin Shasana villages around Puri (JTC, VI, pp. 1376-8) .

3 Sanad of Lord Ripon, Simla, 29 March 1884, JTC, VI, p. 1422.

4 This case is also known under the name of Madhusudan Das, the lawyer of the Puri Raj-family. His picture is still to be seen in the "reception Chamber" in the Puri palace. 
daily worship of the great shrine, to be the incarnation of the great Mahadev Juggernath himself. ${ }^{5}$

How did these Rajas of Khurda or Puri attain such a venerated position among "the wealthier Rajas of Hindoostan", when they had lost the last remnants of their small state around Khurda in central Orissa in 1804 and were only later on (as "Rajas without a kingdom") reinstalled by the British government as the Superintendents of the Jagannatha temple of Puri? To find an answer to this question one has to go back to the medieval history of Orissa as well as to the history of British connections with "idolatry" in India. ${ }^{6}$

The history of the Khurda dynasty (about 1575-1804 A.D.) and of its successors in Puri has not yet attracted the attention of scholars outside Orissa. This is rather astonishing, considering that the Khurda dynasty provides an outstanding example of the foundation and legitimation of a political institution through the possession of a sacred temple-city. The direct relationship between the kings of Khurda and the Jagannatha cult of Puri, though one of the least-known aspects of this cult, is most fascinating. Furthermore, the history of the Khurda dynasty clearly illustrates one phenomenon which we find throughout the history of India: that of a local dynasty deriving its legitimacy from an older, imperial tradition.

This imperial tradition of Orissa is strongly linked with the Hindu God Jagannatha who became the state deity (rashtradevata) of Orissa under the imperial Gangas (c. 1112-1435 A.D.) and the Suryavamsha dynasty (1435-1540 A.D.). Under the Gajapati kings ("Lords of the elephants") of these dynasties Orissa was a strong Hindu bulwark against the Muslim powers of northern and central India for more than three centuries. Though it had been in existence for centuries, ${ }^{7}$ the Jagannatha cult rose into prominence only under the Eastern Ganga king, Anantavarman Codaganga, who started to build the present monumental Jagannatha temple in Puri some decades after he had conquered Orissa in about 112 A.D. The Vaishnava Jagannatha cult, with its strong Shakta, Shaiva, Tantristic and even tribal influences, ${ }^{8}$ seems to have fitted in best with the syncretistic religious policy of Codaganga and his successors. ${ }^{9}$ The construction of a huge temple for Purushottama (the early name of Jagannatha) through the "outsider", Codaganga, was both an act of reverence to an important regional deity of Orissa and a chance of uniting various religious cults of Orissa in the concept of the new state deity of the Gangas.

Under the twelfth-century Gangas, however, Jagannatha remained only a subsidiary state deity of Orissa proper, Orissa being merely the northern part of the

5 Statesman, 2 April 1887, quoted by $\mathbf{P}$. Mukherjee, op. cit., p. 558. My emphasis.

6 W. F. B. Laurie, Orissa, the Garden of Superstition and Idolatry: including an Account of British Connexions with the Temple of Jagannath (London, 1850).

7 K. N. Mahapatra, "Antiquity of Jagannath-Puri as a Place of Pilgrimage", Orissa Historical Research Journal, III, no. I (1954), 296-306.

8 H. Kulke, "Some Remarks about the Jagannatha-Trinity", Indologentagung 1971, ed. H. Härtel and V. Moeller (Wiesbaden, Steiner, 1973) pp. 128-9. See also the forth- coming article of Anncharlott Eschmann, Orissa Research Project, "The Renewal of the Goddess: Prototypes of Jagannatha's Nabakalebara Ritual in the Hinterland of Puri" (to be published in the Orissa Historical Research Journal).

9 Usually Codaganga is looked upon as a convert under the direct influence of Ramanuja, the famous south Indian Vaishnava reformer. A critical analysis of his inscriptions, however, clearly reveals, that he remained a Shaivite who, out of political reasons, called himself in a few inscriptions also a "parama-vaishnava". 
Ganga empire. It was only under king Anangabhima III (1211-1238 A.D.) that Jagannatha became the state deity of the Ganga empire as a whole. After northern India was conquered by Muslim forces in the late twelfth century, Anangabhima systematically reorganised his empire to protect it from the Muslim armies. Among other achievements he built a new capital, Cuttack, on an island in the Mahanadi river and ambitiously named it the "New Banares"- that holiest town of the Hindus having been desecrated by the Muslims a few decades earlier. In this new capital he erected a huge temple to Jagannatha and dedicated his empire to this new state deity. The famous Oriya temple chronicle from Puri, Madala Panji, preserves this tradition: "Anangabhima announced: 'my name is from now Purushottama.' Staying in this city Kataka [Cuttack] Shri Purushottama (= Anangabhima) dedicated everything to the god Shri Jagannatha and remained as his viceroy (rautta)."10 In a series of inscriptions dating from his later years Anangabhima describes himself as the "son of Purushottama" acting as the deity's viceroy (rautta) under his advice (adesha) and authority (samrajya)..$^{11}$

There can be no doubt that this dedication of the Orissan empire to the state deity, Jagannatha, had a strong impact on the Oriyas and the Hindu world. Any service rendered to the king Anangabhima became a service to Jagannatha, the overlord (samraja) of Orissa. It is not surprising, therefore, that some of his successors followed his example and called themselves rauttas under the samrajya of Jagannatha. ${ }^{12}$ Kapilendra (1430-1467 A.D.), the usurper of the Gajapati throne and founder of the Suryavamsha dynasty of Orissa, went even one step further and called himself the elect of the god Jagannatha, ${ }^{13}$ making Jagannatha witness of his actions:

Oh, Jagannatha! Thus prayeth Thy servant: throughout the kingdom I maintained from childhood these [feudal] lords [or nobles] including the infantry and cavalry and gave them wealth. All of them have forsaken me. I shall deal with them [and] punish them each according to his desert. Oh Lord! Jagannatha! do Thou judge . . . whether I am right or wrong. ${ }^{14}$

Furthermore, many of his inscriptions ended with the explicit warning that any resistance to his orders would constitute a treacherous attack (droha) upon the state deity, Jagannatha.

The most important consequence of this Jagannatha ideology, which developed under the later Gangas and the kings of the Suryavamsha, was the undisputed position of Jagannatha as the state deity of Orissa-which had tremendous impact on the further cultural development of Orissa. Politically, it meant that only those kings in possession of Puri and its Jagannatha temple were recognized as the legitimate Gajapatis and rulers of Orissa.

10 Madala Panji (Rajabhoga Itihasa) ed. A. B. Mohanty (Bhubaneswar, Utkal Univ., 2nd ed., 1969), p. 27.

11 T. V. Mahalingam, "Two Eastern Ganga Inscriptions at Kanchipuram", Epigraphia Indica, XXXI (1955), 96-7; D. C. Sircar, "Nagari Plates of Anangabhima III; Saka 1151 and 1152", Epigraphia Indica, XXVIII (1949), 256 f.; D. C. Sircar, "Bhubaneswar Inscription of Anangabhima III; Anka Year 34", Epigraphia Indica, XXX (1954), $22 \mathrm{f}$.

12 D. C. Sircar, "Ganga Bhanudeva II and
Purushottama-Jagannatha", Journal of the Kalinga Historical Research Society, I, no. 3 (1946), 251-3.

13 Madala Panji, p. 42; see also P. Mukherjee, The History of Medieval Vaishnavism in Orissa (Calcutta, R. Chatterjee, 1940), pp. 41-3.

14 Jagannatha Temple inscription of Kapileshvara Deva of 25 April 1464 A.D.; K. B. Tripathi, The Evolution of Oriya Language and Script (Cuttack, Utkal Univ., 1962), p. 272 . 
This situation became most evident after the downfall of the last independent Hindu dynasty of Orissa. The destruction of the central power of Orissa in 1568 by the Afghan armies and the demolition of the wooden sculptures of Jagannatha and his brother and sister, Balabhadra and Subhadra, by the Afghan general Kalapahar seemed to have ended this system abruptly. ${ }^{15}$ In the following years, however, King Ramacandra Deva from south Orissa succeeded in building up a small kingdom in about 1572 A.D. with its capital Khurda to the southwest of Bhubaneswar.

Notwithstanding Ramacandra's considerable military and administrative successes, his future political power was mainly attributed to his installation of new wooden images of the Jagannatha Trinity in the Puri temple. Ramacandra probably kept these new carvings for quite a few years in his fort (gada) at Khurda until he was able to extend his power to Puri. It is unlikely that this happened before $1580 .^{16}$ A legend appeared about Jagannatha's reinstallation, which even today plays an important role both for the continuity of the Jagannatha cult and for the legitimacy of Ramacandra and the future dynasty of Khurda and Puri. The Madala Panji chronicle describes how Bisar Mohanty, a pious Oriya, was able to rescue the most sacred portion of the Jagannatha image after Kalapahar had burnt the wooden carving on the banks of the Ganga. Bisar Mohanty took this "Brahman"-the unburnt portion of the original image-to Kujang, a princely state on the coast of northern Orissa. ${ }^{17}$ Whereas the Madala Panji only mentions that Ramacandra brought this "Brahman" from Kujang to Khurda, the Cakada Pothi, an Oriya text of the Mughul period, relates that Ramacandra was ordered in a dream to bring this "darubrahman murti" (the surviving fragment) from Kujang, to consecrate a new image of Jagannatha, and to place the "darubrahman murti" inside this new sculpture. ${ }^{18}$ Ramacandra's achievement for "the betterment of devatas [gods] and Brahmins"19 was highly appreciated by the Oriyas. According to the Madala Panji, during the grand ceremony in the Jagannatha temple at Puri sanyasins and brahmacarins in the Jagannatha temple accepted mahaprasad (sacred food) from the king, and then "all the Sanyasins, Brahmacarins and Brahmanas called the Maharaja Racamandra the 'Second Indradyumna' and gave him the turban". ${ }^{20}$ Receiving the epithet "the second" or "new" Indradyumna was, without doubt, a great success

15 According to Ni'mat Allah's Makhzani-Afghana the wealth of Jagannatha must have been immense: "Ni'mat Allah says that every Afghan, who took part in the campaign, obtained as booty one or two gold images. Kala Pahar destroyed the temple in Puri which contained 700 idols made of gold, the biggest of which weighed 30 man". M. A. Rahim, History of the Afghans in India A.D. 1545-1631 (Karachi, 1961), pp. $177 \mathrm{f}$.

16 Usually the date of the reinstallation of the images is accepted as 1575 A.D. (K. N. Mahapatra, Khurudha Itihasa Bhubaneswar 1969, p. 15). P. Mukherjee, op. cit. p. 8-10, doubts very much whether Ramacandra was able to bring these new sculptures to Puri by 1575 . According to him "during the reigns of Daud and Qutlu Khan Lohani (till 1584) Jagannatha was worshipped at Khurda and not at Puri". There are good reasons for following $\mathbf{P}$. Mukherjee. The third version of the Madala Panji also speaks of anarchy (arajaka) in Orissa lasting until S. 1502 (1580 A.D.) : p. 62.

17 Madala Panji, p. 62.

18 Cakoda Pothi o Cakoda Basana ba Cayini Cakada, ed. Sudhakar Pattnaik (Cuttack, 1959) pp. 6-7. For a functional analysis of a south Indian temple legend see $\mathbf{H}$. Kulke, "Funktionale Erklärung eines südindischen Mahatmyas. Die Legende Hiranyavarmans und das Leben des Cola Königs Kulottunga I", Saeculum (Freiburg), XX (1969) , 412-22.

19 Cakoda Pothi, p. 7.

20 Madala Panji, p. 63: "duti Indradyumna"; Cakoda Pothi, p. 7: "nabina [new] Indradyumna". 
for Ramacandra, since the first Indradyumna is the legendary founder of the Jagannatha temple and plays the role of the personified god-king in many legends and Puranas of Orissa. ${ }^{21}$

After this success Ramacandra systematically reorganised the administration of the Jagannatha cult, thus strengthening his political position. He took great pains to establish around Puri new Shasana (Brahmin) villages, whose leaders he invited - together with those of the older Shasana villages - to take a seat in the Muktimandapa Sabha in the Jagannatha temple of Puri, which became the highest authority of Orissa in all questions concerning religion and society. ${ }^{22}$

Most probably the Madala Panji, a most important source for Oriyan religion and history, goes back to Ramacandra's rule. Though its semi-historical portion starts with the (mythical) "Kesari dynasty" of the sixth century, it is very likely that this famous temple chronicle, surviving in the form of bundles of palm leaves, was only begun under Ramacandra around 1600 A.D. or under his immediate successors. ${ }^{23}$ This Oriya chronicle still influences the attitudes of many Oriyas towards their own history, and it is perhaps not far-fetched to compare its role with that of the Old Testament of the Jewish people. Whatever may be the result of further research into whether the chronicle was written or "rewritten" 24 under Ramacandra, it can be taken as an established fact that the Madala Panji became the main authority for the legitimacy of the Khurda Rajas and, as we shall see, for the rights of the Puri Rajas under British rule.

Ramacandra's position was further strengthened when Mansimha, Akbar's famous general, finally defeated the Afghans of Orissa in 1592. Against the legitimate claims of the sons of Mukundadeva, the last independent ruler of Orissa, Mansimha recognized Ramacandra as the ruler of Khurda, and appointed him in Puri as the superintendent of the Jagannatha temple, thus installing him as the legitimate successor of the Gajapatis of Orissa. ${ }^{25}$ Mansimha, himself a Hindu, had certainly

21 For example the Purushottama Mahatmya of the Skanda Purana. See the forthcoming monograph on Indradyumna by $R$. Geib, Orissa Research Project, Die Indradyumna-Legende. Ein Beitrag zur Geschichte des Jagannatha Kultes (Wiesbaden, Harrassowitz, in press).

22 Georg Pfeffer, anthropologist and member of the Orissa Research Project, is publishing a monograph on "The Shasana Villages of Orissa-the Basis of a Regional Elite."

23 This is not the place to enter into the still very controversial discussion of its age. To quote D. C. Sircar: "R. P. Chanda is no doubt quite right when he says, as the foreigners who invaded Orissa in the fifth century A.D. are called Mughals (in all the versions of the M.P.), it may be safely concluded that the sections relating to the preMoghul period of these texts were first compiled in the Mughal period"." D. C. Sircar, "The Madala Panji and the pre-Suryavamsi History of Orissa", Journal of Indian History, XXXI (1953), 233-46. K. C. Panigrahi, who made a detailed study of the printed texts of the Madala Panji, arrived at the same conclusion on independent grounds. $\mathrm{He}$ is of the opinion that the Chronicle was written during the reign of Ramachandra I or his successors. (Itihasa o Kimbadanti, Bhubaneswar, Utkal Univ., 1963, p. 68.) G. N. Dash, Orissa Research Project, tried to prove that the Madala Panji was written under Ramachandra's grandson, Narasimha: "Madala Panji, eka tippani", Dagara, XXIV, no. 12 (1961), He is now preparing a monograph on this subject.

24 H. K. Mahtab, The History of Orissa (Cuttack, 1960), II, 459. In the first edition (1948) of his Odisha Itihasa (Oriya) H. K. Mahtab mentions that Ramachandra ordered one Bateshwar Mahanti to write the Madala Panji in order to prove his legitimation to the Gajapati throne when Mansimha came to Orissa.

25 Madala Panji, p. 63 f.; N. K. Sahu, "Orissa from the Earliest Time to the Present Day", A History of Orissa, ed. N. K. Sahu (Calcutta, Susil Gupta, 1956), II, 391 speaks of Ramachandra as "the Phantom Gajapati of Orissa". 
taken into consideration the position which in the meantime Ramacandra had gained in the Jagannatha cult. ${ }^{26}$ The power of Ramacandra's dynasty thus received a double legitimation, which raised it high above the other feudatory rajas of Orissa: beside the traditional legitimation through the Jagannatha cult Ramacandra received the imperial legitimation from the Mughals, which was again to become of great importance under British rule. The remnants of the old Orissan empire were distributed by Mansimha among various local dynasties. "Under the [Khurda] Raja's command are thirty zamindaris of Hindu Sirdars containing one hundred and twenty nine Killahs. The jurisdiction thus left to the Raja of Khurda extended from the Mahanadi to the borders of Kimeda in Ganjam [south Orissa]." 27 The districts of Balasore, Cuttack, and parts of Puri district came, as "Mughalbandi", under the direct rule of the Mughals.

After Akbar's death the policy of the Mughul Subahdars - or provincial governors -of Cuttack towards the Khurda dynasty and "its" Jagannatha temple changed rapidly. The history of the Khurda dynasty during the seventeenth and early eighteenth centuries is characterized by frequent attacks on the part of Mughul armies upon the Jagannatha temple in Puri. ${ }^{28}$ It is sad to discover so many places in Orissa where the "National God of Orissa" had to be hidden, and even buried; the trauma experienced by the Oriya people, when both Jagannatha and the Gajapatis had to flee to remote areas of Orissa, seems to have strongly influenced the relationship between the people, Jagannatha, and the Gajapati kings. But in spite of their many raids, some Mughul Subahdars in Cuttack were not anxious for the complete destruction of Jagannatha's temple and cult. This "toleration" had economic reasons, too: "The absence of Jagannatha from his temple caused a loss of Rupees nine lakhs $[900,000]$ which the pilgrims paid as tax." 29

\section{III}

In this situation, which became increasingly desperate, the Khurda Rajas systematically made use of their state deity, Jagannatha, and of their own position in this cult. The kings of the powerful Gangas and Suryavamshas had confined the Jagannatha cult to the political and religious centres of their empire-Cuttack and Puri-and had used the religious authority of Jagannatha to threaten their political opponents. The Khurda Rajas, having lost the power to monopolize this state cult of Orissa, now tried instead to assure the support of their feudatory rajas (samanta rajas) by "sharing" their position in the Jagannatha cult with them. ${ }^{30}$ This was done in official sanads by conferring new titles upon them and giving them special rights in the Jagannatha cult at Puri. In the Jagannatha Sthala Vrttantam, a Telugu text which probably had been compiled shortly after 1800 for Colonel Mackenzie, we fortunately find a list of sanads granted by the Khurda Rajas to

26 K. N. Mahapatra, "Gajapati Ramachandra Deva I", Orissa Historical Research Journal, VI, no. 4 (1958), pp. 227-50.

27 A. Stirling, An Account, Geographical, Statistical and Historical of Orissa Proper or Cuttack (repr. 1904), pp. $66 \mathrm{f}$.

28 For the humiliating life of Ramacandra's successor Purushottama Deva and for the attacks of the Mughals on the Jagannatha temple under his reign, see Baharistan $i$ Ghaybi, ed. M. J. Borah (Gauhati, 1936), I, 35-8.

29 Mukherjee, op. cit. p. 21.

30 H. Kulke "Kshatriyaization and Social Change in Post-Medieval Orissa", Changing India. Studies in Honour of Professor G. S. Ghurye, ed. S. D. Pillai (Bombay, Popular Prakashan, in press). 
feudatory rajas of Orissa. ${ }^{31}$ This list of "Privileges of darshana of Shri Jagannatha given to Khandayats [subordinate kings] at Shri Purushottama Temple" records about thirty-seven visits by various rajas, mainly from Orissa, to Puri, which cover a period from about 1654 to 1801 . With a few exceptions the Rajas of Khurda granted royal visitors special rights during these visits. These rights ranged from the permission to enter Puri with certain royal status symbols-for example, mounted on elephants, in palankis, or with torches (masala) - to the privilege of special sevas in the Jagannatha temple (for example, camara-seva or curi-khanda-seva, that is holding a spear(?) and sword in front of Jagannatha). Other rajas received new titles after having had darshand - a view or "audience"-or were even granted the rights of a "pariksha" (superintendent) of the Puri temple, as in the cases of the Rajas of Banki and Athagada.

It would be worth undertaking a separate study to show how many of these privileges were granted under certain political circumstances. For the purpose of this paper, however, it may suffice to give one example. After a series of brave but futile fights against the Mughal Subahdar, the Khurda Raja, Ramacandra II, was finally dethroned and converted to Islam (see below) and in about 1736 Padmanabha Deva of Patia was made king by the Mughals. With the help of his samanta rajas, Ramacandra's son Virakesari Deva successfully regained the throne of Khurda in about $1739 .^{32}$ Virakesari, in spite of the damaging inheritance of his father (who as the "sacred" Gajapati had become a Muslim and was then dethroned), thus became king of Orissa at a time when the reputation of the Khurda dynasty was very much on the decline. From the list of those sanads which are recorded in the Jagannatha Sthala Vrttantam it seems very likely that Virakesari in this situation systematically tried to assure or regain the support of his samanta rajas through special honours during their visits to the Jagannatha temple or by granting special rights in the temple as a reward for their support. In the years between 1745 and 1750 such rights were given to the Rajas of Banki, Khandpara, Ranpur and Athagada in central and southern Orissa.

The example of Athagada in south Orissa is most illustrative. The rajas of this state had helped Ramacandra II who during his fights with the Mughal Subahdar of Cuttack had taken shelter several times in Athagada together with the carvings of the Puri Trinity. His son Virakesari in his thirteenth anka-year (1746 A.D. $)^{33}$ granted the title of "Haricandana Jagaddeva" to the Athagada Raja when he came to Puri for a darshana of Jagannatha. In his fourteenth anka (1747) Virakesari wrote the following letter to the Raja of Athagada:

As you have been engaged in a very difficult task in our favour, Bakshi Hamir Khan has been sent to Banapur [in south Orissa]. You should join him and help him to accomplish the work entrusted to him on our behalf. Showing favour to you, we have appointed you as the Pariksha [Superintendent of the temple of

31 Jagannatha Sthala Vrttantam Ms. D. No. 2612 Government Oriental Manuscript Library Madras. (Descr. Dat. of Telugu MSS). This manuscript was "discovered" by the author while searching in the Madras libraries for further manuscripts on the history of the Jagannatha cult. It has now been translated by Padmasri S. N. Rajaguru, Government Epigraphist of Orissa, and will be published by him together with the author in 1975 by the South Asia Institute, Heidelberg.

32 S. C. De, "A Grant of Land to Lord Jagannatha of the Time of Padmanabha Deva", Orissa Historical Research Journal, III (1954), 40-3.

33 In the still controversial problem of calculating the anka-years of the Khurda Rajas I rely on K. N. Mahapatra, Khurudha Itihasa (Bhubaneswar, 1969). 
Shri Jagannatha]. You should maintain the services of the gods carefully and in a proper manner. Our other [secret] message you will learn from this letterbearer's mouth.

In another letter, obviously written after the Athagada Raja had finished his task, Virakesari replied to that Raja: "You have requested us to grant the privilege of beating a big drum (nagara) on the back of elephant. Your request has been granted by us." In a fourth letter further rights were granted and the former confirmed:

Showing favour to you we have been pleased to grant you privileges namely: use of amvari (royal seat) on elephant's back where also a big drum (nagara) would be placed; use of vehicle drawn by a pair of horses; appointment as Pariksha of the temple of Shri Jagannatha Mahaprabhu; a house containing one hundred rooms in Shrikshetra (Puri) together with a garden and one hundred batis of land for performing the services at the main temple as Pariksha. Apart from the above privileges you are also allowed to use a flag called 'Khagasamala Bana'. ${ }^{34}$

\section{IV}

Despite these efforts, the eighteenth century witnessed the downfall of the Khurda dynasty. Ramacandra II's fate has already been mentioned. After a long struggle with the Mughal Subahdar at Cuttack he was imprisoned at the Barabati fort there and forcibly converted to Islam. The Madala Panji, not without a touch of irony, relates: "The raja was caught and imprisoned in Cuttack. After some days had passed this king was defeated by the daughter of the Nawab and was driven out of caste. He had contacts with the Pathans." 35 As a Muslim with the name Hafiz Quadir and married to a Muslim princess, Ramacandra was no longer allowed to enter the Jagannatha temple in Puri. Most probably he also lost the superintendence of the temple. After Padmanabha of Patia (a direct descendent of Mukundadeva, the last independent ruler of the Orissa Empire) was enthroned by the Mughals, the Khurda dynasty had lost both legitimations of its power: the traditional legitimation as Gajapati Kings of Orissa and first servant (sevaka) of the state deity Jagannatha; and the imperial legitimation through the Mughals. Ramacandra's son, Raja Virakesari, succeeded temporarily in regaining the Khurda dynasty's old "double" position as Maharaja of Khurda and "sacred" Gajapati of Orissa with its religious centre at Puri. However, the final blow to the Khurda Raja's position was soon struck by a Hindu dynasty.

In 1751 the Marathas occupied Orissa. It took them only a very short time to diminish the power of their ally, the Khurda Raja Virakesari, to that of a zamindar or local raja. Soon after the Marathas had conquered Orissa, Jagannatha Narayana Deva, Raja of Khimedi in south Orissa, invaded central Orissa, defeated Virakesari and resided for some days in Puri. Narayana, as a scion of the old imperial Ganga dynasty, challenged the claim of the Khurda Raja to be the lawful Gajapati of Orissa. With the help of the Marathas, Narayana was driven out of the Khurda territory. "Virakesari agreed to pay one lakh of rupees to the Marhattas. As he did not pay they [the Marathas] took away the administration of [the parganas] Lembai, Rahanga, Purushottama and 14 Garhjats [feudatory states of Khurda]."36

34 Jagannatha Sthala Vrttantam.

35 Madala Panji, p. 77.

36 Ibid., p. 79; B. C. Ray, Orissa under the
Marathas (Allahabad, 1960), pp. 130-2; K. N. Mahapatra, Khurudha Itihasa, p. 205. 
The consequences of this incident proved to be disastrous for the Khurda dynasty. Virakesari lost the most important part of his realm, "Purushottama Kshetra", that is, Puri and its Jagannatha temple. Though still Maharajas of the small state of Khurda, the Khurda Rajas lost their most important functions as Gajapati kings in the Jagannatha cult, which had been the very base of their authority and power over the Garhjat chiefs and which had determined their position in Hindu society. The Maratha Rajas of Berar (Nagpur) took over the administration of the Jagannatha temple. ${ }^{37}$ According to the "Account of the Gangavamsha of Odra-Desha", the Maratha Governor of Orissa, Sivabhatta (Sheo Bhatt Sathe[?], 1760-64) performed the important "Turban ceremony" for the Garhjat chiefs of Orissa in front of Jagannatha in Puri. ${ }^{38}$ In this respect it is noteworthy that the temple chronicle of Puri gives a detailed description of the meritorious acts which were performed in Puri by Brahmacarin Gosvamin, the guru of the Marathas. The chronicle, howver, is silent about any grants by Divyasimha Deva (1781/93-1795), the successor of Virakesari. ${ }^{39}$

The occupation of parganas like Lembai and Rahang might be explained as a means by which the Marathas attempted to recover their debts from the Khurda Raja. The separation of fourteen Garhjat states from the influence of the Khurda Raja, however, has to be understood as a political manoeuvre by the Marathas designed to weaken the influence of the Khurda Raja outside his own territory. In this respect the observations of T. Motte, one of the earliest British travellers in Orissa (1766), are most instructive:

When Ragoojee [of Nagpur] entered Orissa he found these parts divided into small zemindaries, dependent on the rajah of Pooree, at whose capital is the famous temple of Jaggernaut, near the Chilka lake. This prince was regarded by his subjects in a religious light also, and appeared formidable to the Mahrattas, who, apprehensive lest he might seize a favourable opportunity to cut off the communication between Nagpoor and Cuttack, resolved to reduce his power by dividing it. He made the petty zemindars independent of him, and formed the chucklas of Dinkanol (Dhenkanal), Bonkey (Banki), Nersongpoor (Narsinghpur), Tigorea (Tigeria), Tolchair (Talcher), Chundaparra (Khandapara), Dispulla (Daspalla), Hindole (Hindol), Ungool (Angul) and Boad (Baud). ${ }^{40}$

It is understandable that a Hindu dynasty like the Marathas of Nagpur, as the new masters of Orissa, were suspicious of the position held by the Rajas of Khurda. The important role of the Khurda Raja in the Jagannatha cult and his close relationship with the feudatory rajas of the Garhjat states made the Gajapati appear the "secret" ruler of Orissa. Consequently the Marathas took over the administration of the

37 Ray, op. cit., p. 131. It is most significant that in her case against the British Government Rani Suryamani (wrongly!) quoted the Madala Panji to prove that during the Maratha period, too, the Rajas of Khurda "managed the affairs" of the temple: Petititon of Ranee Suryomani Patmahadei, 18 July 1882, JTC, VI, p. 1370.

38 "Account of Gangavamsha of OdraDesha", in Local Records, XLVII, 9-14, Government Oriental Manuscript Library. (The compiler of this Telugu MS. must have known the Rajabhoga Itihasa of the Madala Panji): "During this moment Narayana- deva of Khemundi again visited Puri for darshan of Shri Jagannatha Mahaprabhu and received the honour of Shirupa [royal turban] before the great god from the hand of Shivabhatta, the Maharatha chief" (translated by Padmasri S. N. Rajaguru).

39 Madala Panji, pp. 80-1.

40 Quoted by P. Acharya, Studies in Orissan History, Archaeology and Archives (Mayurbhanja, 1969), p. 247: A chakla (corruptly chuckla) is "a large division of a country, a number of Parganas". See H. H. Wilson, Glossary of Judical and Revenue Terms (repr. Delhi, 1968), p. 98. [My emphasis.] 
Jagannatha temple and "freed" fourteen Garhjat states. It is interesting to note the extent to which the Marathas, after only a few decades, had identified themselves with the "Gajapati role" of Orissa: after the British conquest of Orissa in 1803, the ambassador of the Maratha king of Berar tried hard in his peace negotiations with the East India Company to regain at least Puri: "Jagannath was his [the Raja of Berar's] own pagoda, he was desirous to retain it [and] . . his honour was involved in this point." 41 The British authorities seemed to have a clear picture of what it meant to the Maratha Raja to lose Jagannatha: "The Governor General pointed out that the loss of Juggernaut must deeply affect the considerations of the Rajah of Berar in the eyes of all native powers."42

To sum up: on the eve of the British occupation of Orissa in 1803 the Raja of Khurda was deprived of more than half of his state, separated from his feudatory rajas in the hinterland of Orissa, and driven out of the superintendence of "his" Jagannatha temple. However, there was still a strong feeling among the Oriyas that he was the "fallen, but revered descendent and representative of their ancient native sovereigns". ${ }^{43}$ These facts strongly influenced the British policy in Orissa during the first half of the nineteenth century.

\section{V}

During the preparations for the war against the Marathas the East India Company was very much aware of the importance of the Jagannatha temple, since "in a political light its value is incalculable". ${ }^{44}$ The Governor General, Lord Wellesley, wrote a famous letter to Colonel Campbell, the commanding officer of the British invading forces in Orissa. In this letter "for the first time, a Christian Governor General dictated a policy to be pursued regarding a particular Hindu temple" ${ }^{45}$

On your arrival at Juggernath, you will employ every possible precaution to preserve the respect due to the Pagoda, and to the religious prejudices of the Brahmins and pilgrims. You will furnish the Brahmins with such guards as shall afford perfect security to their persons, rites and ceremonies, and to the sanctity of the religious edifices, and you will strictly enjoin those under your command to observe your orders on this important subject, with the utmost degree of accuracy and vigilance. ${ }^{46}$

Colonel Campbell, while on the march to Puri was met several kilometres outside the town by a Puri Brahmin who informed him that "the Brahmins at the holy temple had consulted and applied to Jaggernaut to inform them what power was now to have his temple under its protection, and that he has given a decided answer that the English Government was in future to be his guardian."47 After the British troops had occupied Puri on 18 September 1803, John Melville, the newly-appointed Civil Commissioner of Cuttack did not hesitate to use Lord Jagannatha's "decided

41 Home Miscellaneous, Vol. 623, pp. 86 111, quoted in B. C. Ray, op. cit., p. 126.

42 Selection from the Wellesley Despatches, p. 410. Quoted by P. Mukherjee, op. cit., p. 50 .

43 Correspondence of the Settlement of Khoordah in Pooree. From W. Ewer, Commissioner to W. B. Bayley, Act. Chief Secr. to Gov., 13 May 1818. Reprinted Orissa Historical Research Journal, III, no. 4
(1955), p. III.

44 John Melville to Shawe (Private Secretary to Wellesley), Juggernauth, 11 July 1805 (Wellesley papers Add. MS. 13611).

45 P. Mukherjee, op. cit., p. 42.

46 Wellesley to Campbell, 8 Aug. 1803, Parliamentary Papers, $1845 / 664$, p. 76.

47 Melville to the Governor General, 11 Sept. 1803, Parliamentary Papers 1845/664 p. 77. 
answer" as a strategem to win over the feudatory chiefs of Orissa. Melville informed the Governor General: "I have sent by special messengers to some of the principal Rajahs letters as my judgment tells me were best adapted to the mentioned purpose and the circumstances of Jaggernaut's decision (which was a fact) was not omitted". ${ }^{48}$ Thus the Christian government of the British East India Company during the early years in Orissa was following the line of the Hindu rajas, using Jagannatha as a medium to influence political decisions.

The Jagannatha cult and its temple also played an important role in the economic and even military considerations of the East India Company during the first decades of the nineteenth century. John Melville, one of the two first British Commissioners of Orissa, wrote a very enthusiastic letter about his observations at the great car festival of the year 1805, after praising the "order and regularity" of the "at least five lacks [sic]" of pilgrims, he described his general impression which "is highly favourable to the British Government". Then he came to the point:

On all occasions when the subject of that valuable acquisition the province of Cuttack, is under consideration the important possession of the temple of Jaggernaut must stand in a prominent point of view; in a political light its value is incalculable and even as a source of Revenue to the state it will be found of great consequence, as under the protecting influence of the British Government the number of Pilgrims will so greatly increase that it becomes difficult to make a comparison between the amount which the tax formerly yielded and what it may now be reasonable expected to produce, it may be nearer eight lacks than two per annum. ${ }^{49}$

In his "Scetch of the History of Orissa from 1803 to 1828 " G. Toynbee therefore rightly observed that "Pooree was doubtless selected [as the Collector's headquarter until 1816] on account of its importance in connection with the pilgrim tax and the temple." 50

As long as the Marathas were able to endanger the communications between the Madras and Bengal Presidencies, Orissa as an essential link between both, played an important role in the strategic and military plans of the East India Company. In the year 1810 a Bengal Maharaja offered Rs 150,000 for the construction of the "Jagannatha Road" between Calcutta and Puri. The Company was willing to accept this money since

a road in that direction is an object highly desirable, considered only with respect to the reputed sanctity of the Temple, the great number of pilgrims who annually resort to it, and to the general convenience of the community. It is however still more essentially requisite in a military point of view, for the purpose of affording a free communication between the provinces immediately dependent of the presidency of Fort William, and the territories subject to the Government of Fort St. George. ${ }^{51}$

48 Melville to the Governor General, 19 Sept. 1803, Secret and Political Consultations: 1 March 1804 No. 14, India Office Records; quoted by P. Mukherjee, op. cit., p. 44 .

49 As in $n .44$ above.

50 Reprinted in the Orissa Historical Research Journal, IX, nos 3/4 (1961), App. p. 31. For the pilgrim tax see the comprehensive Webb Report. George Webb to Board of Revenue, 19 Dec. 1807, JTC, XII.
See also J. Peggs, Pilgrim Tax in India; Facts and Observances Relative to the Practice of Taxing Pilgrims in some Parts of India and Paying a Premium to those who Collect them for the Worship of Juggernaut at the Great Temple in Orissa (London, 1830).

51 Extract Revenue letter from Bengal, 12 Feb. 1811, Parliamentary Papers, 1812-13/ 194, p. 512. 
The central British policy regarding the Jagannatha temple and its priests was the principle of confirming "the confidence of the Brahmins and officers of the temple of Juggernath in the liberality and protection of the British Government." 52 The British, therefore, guaranteed all the rights which were granted to the priests at Puri by previous governments, and even agreed to continue the yearly payment of an excess amount of nearly Rs 60,000 for the maintenance of the temple, a financial aid which was introduced by the Marathas. For some years they also took over the direct supervision of the Jagannatha temple administration.

However, the participation of the British East India Company in the administrative affairs of an "idolatry temple", the annual payment of a considerable amount of money for its maintenance, and the collection of taxes from Hindu pilgrims came under increasing criticism from the British Government and especially the Christian missionaries. This criticism and the realization that British officers, being forbidden entry into the temple as non-Hindus, could not arbitrate fully in the temple management, forced the East India Company to sever its connection gradually with the temple, without, however, openly giving up the responsibility and commitments which it had assumed for political reasons during the conquest of Orissa.

\section{VI}

It was this situation which forced the British Government gradually to hand over the administration of the Jagannatha temple to the Raja of Khurda. After a period of trial and error, ${ }^{53}$ the superintendence of the temple was vested in the Raja of Khurda by Regulation IV of 1809 and finally confirmed by Act X of 1840 . At the same time the pilgrim tax was abolished. Thus the Rajas of Khurda, who had been ousted from the sacred office of the first sevaka of Jagannatha by the rival Hindu dynasty of the Marathas of Nagpur, were reinstalled in this position by a Christian Government.

Let us now turn back to these Rajas of Khurda. From the very beginning their relationship with the East India Company had been determined by the earlier loss of the four parganas together with the Puri temple to the Marathas. ${ }^{54}$ In 1803 Raja Mukunda Deva II (1795-1817) had supported the British troops against the Marathas, and so he assumed that the British would help him to regain his lost territory. Receiving no such help immediately after the British conquest of Orissa, he marched to Cuttack in March 1804 with an army of 2000 men in order to interview the Commissioner, Mr Harcourt. But Harcourt made it clear that "not a span of land could be given up".55 After further fruitless "negotiations", Mukunda Deva became bitterly disappointed and took matters into his own hands. He tried to regain influence in the Puri temple or as Toynbee puts it "he was detected in an intrigue relative to the affairs of the Pooree temple". The British reaction to these attempts was very similar to that of the Marathas. Mukunda was "forbidden to

521 Nov. 1803, Parliamentary Papers, $1845 / 664$, p. 78.

53 K. M. Patra, Orissa under the East India Company (New Delhi, 1971) pp. 22339 and idem, "The Management of Jagannath Temple During the East India Company's Administration of Orissa", Bengal Past and Present, LXXXVIII (1969), Pp. 61-81.
54 "When we took the province in 1803 , the Raja passively espoused our cause and tendered his allegiance to the British Government. doubtless in the hope that these parganas would be restored to him". G. Toynbee, op. cit., p. 7.

55 B. C. Ray, Foundations of British Orissa (Cuttack, New Students Store, 1960), p. 50. 
issue orders on any person whatever residing within the limits of Mughalbandi territory [which was under British administration] without the express sanction of the Commissioners" ${ }^{56}$ A month later in October 1804, Mukunda revolted openly, supported by the feudatory rajas of Kujang and Kanika in central Orissa.

This revolt was quickly suppressed, the fort of Khurda was stormed, and Mukunda Deva was imprisoned, first in Cuttack and later in Midnapore. His territory was confiscated, which meant the effective end of the Khurda dynasty. It was only the subsequent change of British policy regarding its connections with the Jagannatha temple and other religious endowments in India, which resulted in his release from confinement and made him the superintendent of the Jagannatha temple. From being virtually "Kings without a kingdom", the "Rajas of Puri" succeeded in the following decades in compensating for the loss of their political power by building up a "religious state" through the superintendence of the hereditary temple of the Gajapati kings of Orissa.

One of the first concerns of Mukunda was to improve his ritual and political position among the feudatory rajas of Orissa. He interfered with the above-mentioned "rights" which various feudatory dynasties claimed to have received from previous Gajapati kings of Orissa. Only a few months after he became Superintendent of the Jagannatha temple, the Raja Padmanabha Narayana Deva of Khimedi in southern Orissa visited Puri to have darshana of Lord Jagannatha, but Mukunda would not permit him to enter the temple. After the British Settlement Officer forced the Puri Raja to give him permission, Mukunda Deva persuaded the cooks of the temple not to prepare mahaprasada food. "Upwards of four or five thousand souls" it was reported, "are now starving for want of necessary mahapersad [including] Rajah Puddohlab Narrain Deo and his followers as it is not proper nor comformable in their religion, to cook victuals in their house in Pooree, when they come on pilgramage, but only to live on Mahapersad." ${ }^{57}$ This behaviour of Mukunda Deva seems to be quite understandable when we remember that it was a Raja of Khimedi who, only half a century before, attacked Khurda; a fact which finally led to the confiscation of "Purushottam" by the Marathas. But this treatment of the Raja of Khimedi was not a particular case. At the end of 1813 the Raja of Khandpara, another feudatory state of central Orissa entered Puri with "insignia of Rajahship". This was too much for the Puri Raja, who prevented the Raja of Khandpara from entering the temple. The Raja of Khandpara complained to the Collector "stating that Rajah Muchoondeo prevented him making Durshan with himself and his family in the mode he has been accustomed and that he is agreeable to the customs and rules of the Temple". ${ }^{58}$ Early in 1814 in a letter to the Governor-General, Mr Richardson, Member of the Board of Revenue on deputation to Cuttack, responded "three instances of offensive and contemptuous and disrespectful treatment" by the Raja of Puri against feudatory Rajas of Khemundi and Khandpara and against the Rani of Sambalpur. ${ }^{59}$

Even if there are some doubts which royal insignia were "agreeable to the customs", it seems to be quite evident that after 1809 Mukunda Deva as the

56 Toynbee, op. cit., p. 7.

57 Busby, Collector of Tax to R. Mitford, Collector, Cuttack, 17 May 1810, JTC, I, p. 183.

$58 \mathrm{Mr}$ Trower, Collector to Samuel Busby, 29 Jan. 1814, Orissa State Archives, Vol. Jan. 1814-Dec. 1818: quoted by P. Mukher- jee, op. cit. p. 132.

59 Richardson, Member Board of Revenue on deputation, Cuttack, to Governor-General, 8 Jan. 1814, No. 29, Bengal Revenue Proceedings: quoted by $\mathrm{P}$. Mukherjee $o p$. cit. p. 198. 
Superintendent of the Jagannatha temple tried to restrict the rights of the feudatory rajas of Orissa in "his" Jagannatha temple, which was the only basis of his power. Whereas, before the British conquest of Orissa in 1803, the Rajas of Khurda had tried to strengthen their ties with their feudal samanta-rajas by "sharing" their rights, after 1809 Mukunda Deva, as Raja of Puri, seems to have tried to reverse this development. Just as the Ganga- and Suryavamsha dynasties had tried to "monopolize" the political aspect of the Jagannatha cult, so did Mukunda Deva and his successors to the throne of Puri for their own dynasty.

Mukunda's "ritualistic" fights against certain feudatory rajas of Orissa, which "prevented the southern Rajahs and the Ghurjats from visiting the temple for several years" ${ }^{60}$ were observed with growing suspicion by the British administrators. They suspected him of using his superintendence of the Jagannatha cult for political ends. As early as 1814, Richardson warned the Government at Calcutta:

I am informed by creditable authority sufficient to obtain my entire belief that the Rajah entertains and incalculates the belief that he will one day, through the power and influence of Juggernauth, be restored to the supreme command and authority of the Province of Cuttack, which tradition and family (oral or written) History state to have been invested in his ancestors previous to the establishment of the Musalman authority some centuries ago. ${ }^{61}$

These were prophetic words which presaged the great paik (militia) revolt, which broke out in the former state of Khurda in 1817. After its suppression a commission was appointed to investigate the socio-economic causes of the rebellion, but in his final report to the government in 1818 the Commissioner, W. Ewer, clearly stated that the Raja of Puri was not involved in this revolt. ${ }^{62} \mathrm{He}$ was convinced, however, that the paiks wanted to reinstall Mukunda Deva on the throne of Khurda:

The first step taken by the rebels, after repelling the early movements against them was an attempt to place the Rajah of Khoordah at their head, well aware of the strength which his name would lend to their cause, and of the assistance they might hope, in the event of his restoration, to derive from the whole body of the Gurjat Chiefs, ranged under the banners of this fallen, but still revered, descendant and representative of their ancient native sovereigns. ${ }^{63}$

The insurgents called upon the Raja and Jagabandhu [the leader of the paiks] -issues orders in his name. Their avowed intention is to proceed to Pooree and reconduct him in triumph to his territory. ${ }^{64}$

60 Trower to Richardson 18 March 1814 , JTC, I, p. 219. It was during these years that Mukunda Deva tried again to use the Madala Panji in his political struggle in a similar way as in his inscriptions in the fifteenth-century King Kapilendra threatened his opponents with the wrath of the God Jagannatha (see above): "The Rajah of Khoordah on all occassions where he wishes to give trouble quotes "Madla Panjee" or records of temple... and the Rajah wishes every orders issued by himself to be considered as the same." Trower to Richardson, 18 March 1814, loc. cit.

61 Richardson to Government, 5 Feb. 1814: quoted by Mukherjee, op. cit., p. 137.
62 Ewer, op. cit. n. 43, pp. IV-V: "That the last Rajah of Khoordah ever favoured the designs of his rebelious servants, or even previously acquainted with them, not a particle of evidence is attainable." The Madala Panji, p. 82, however, relates a different point of view: "Both the father [Mukunda] and the son secretly revolted against the British rule and order. They did not openly fight with the English but invoked the paiks and helped them in looting the English treasury [in Puri]".

63 W. Ewer, op. cit., p. III.

64 Impey to Government, quoted by Toynbee, op. cit., p. 17. 
When the insurgents reached Puri in great numbers, "the priests of the temple openly proclaimed the fall of the English rule and the restoration of the authority of the ancient line of sacred kings" ${ }^{65}$ Yet the futile "paik bidroha" put an end once and for all to the Puri Rajas' hopes of regaining their lost territory and of becoming Maharajas of Khurda again.

Mukunda Deva was placed in close confinement in the fort at Cuttack where he died a few months later. His struggle was continued, however, by his successors and indirectly by the propaganda of the British missionaries, who forced the British Government to sever its connections with the Jagannatha temple. A major step in this direction was Act $\mathrm{X}$ of 1840 , which abolished the pilgrim tax and enacted that "the superintendence of the Temple of Juggernaut and its interior economy, the conduct and management of its affairs, and the control over the Priests, officers, and servants attached to the Temple, shall continue vested in the Rajah of Khoordah for the time being." The government at first, however, continued to pay a fixed amount of Rs 56,342 to the Rajas of Puri for the management of the temple. It was most important for their future position that government, under continual pressure from the missionaries, handed over to them various estates successively in lieu of the annual payments. Through these transactions the Jagannatha temple and hence the Rajas of Puri became more and more independent. The last financial links between the Government of India and the Jagannatha temple were cut in 1863. It is interesting to note that during these years the Rajas of Puri had not given up hope of regaining their ancestral estate of Khurda. Raja Virakisor Deva (1856-1862), for instance, hesitated to accept for the maintenance of the Puri temple a portion of the previous Khurda State as "being his own hereditary zamindari", an idea which Cockburn did not hesitate to call "an assertion which appears to be an exceedingly impertinent one". ${ }^{66}$

Through the acts and regulations of 1809 and 1840 the Rajas of Puri had received a kind of imperial British legitimation for their authority over the Jagannatha temple with its ca. 4000 priests and their families. The main source of legitimation for their claim, as Gajapatis of Orissa, to be the Maharajas of Jagannath's sacred empire of Orissa, ${ }^{67}$ was their ritual role in the Jagannatha cult. Being both the "first servant" (adya sevaka) who ritually cleans the cars of the Gods (cherapahamra) before their famous Ratha Yatra (car festival) in Puri, and at the same time being the Calanti Vishnu ("moving Vishnu"-in contrast to the Jagannatha-Vishnu, who stays permanently in the temple), the Rajas of Puri had again reached the topmost position of the traditional hierarchy of Orissa. This development was celebrated-as we have seen in the case of the Rani Suryamanias a victory over the British administrators who had often tried to restrict the power of the "royal superintendent" to that of a shopkeeper. The Rajas of Puri, though without any territorial basis, were able to withstand these pressures, however, not only by means of their sacred role as Gajapatis, but also because of the British policy of non-interference with religious institutions and their endeavours to isolate

65 Toynbee, op. cit., p. 18.

66 Cockborn to Board of Revenue 12 January 1858.

67 The Madala Panji calls Jagannatha the (real) king of Orissa ("Odisa rajya raja Shri Jagannatha", p. 26) and the Purushottama Mahatmya of Vishnurahasyam (Orissa
State Museum, Descr. Cat. of Skt MSS. III, No. 68 , p. 32) calls Jagannatha the universal king (raja-adhi-raja, V, 59). And during certain rituals, "when Jagannatha appears in royal dresses (raja-vesa) he [the Gajapati King] performs his royal rituals [raja-niti]", Record-of-Rights (see below, n. 72), p. 12. 
these institutions from indigenous reform movements which would endanger "the tranquility, good order and regularity" ${ }^{18}$ of Orissa.

Whereas during the nineteenth century the Rajas of Puri were able to regain and strengthen their position as the Gajapatis of Orissa, the twentieth century witnessed a process of decline which has been described by N. Patnaik. ${ }^{69}$ Sketching the changes of the last seventy years, he points out "the growing secularization in the personal behaviour" of the last three Rajas of Puri which led to their neglect of essential palace rituals. This process which was further influenced by growing "economic impoverishment as an important factor for disintegration of sanctity" finally culminated in the Rajas of Puri no longer being "considered godly".

Ramacandra Deva, the grandfather of the present Raja of Puri, perhaps was aware of the diminishing influence and power of his sacred position as Gajapati of Orissa. On the very eve of India's Independence he tried for the last time to regain the ancestral state of Khurda. In a memorial to the Governor General, Ramacandra pointed out:

Your Excellency's humble memorialist cannot forget that his forefathers occupied the honoured position of a Sovereign Power for centuries, exercising unquestioned suzerainty over Garjat [Feudatory] Chieftains most of whom have since been acknowledged as Ruling Chiefs in Orissa. In the case of these Ruling Chiefs, it has been authoritatively announced that all the rights surrendered by the States to the Paramount Power shall be restored to the States, as a sequel to the forthcoming constitutional changes. ... Your Excellency's humble memorialist respectfully submits that the restoration of Khurda to the humble memorialist in full rights of Sovereignity analogous to that of the Orissa States and the acknowledgment of the humble memorialist as the hereditary Raja and Ruler of Khurda will, in his humble submission, constitute a bare act of justice. ${ }^{70}$

But the Rajas of Puri were to wait in vain for an answer to their memorandum.

\section{VII}

After Independence it was the turn of the Government of Orissa to deal with these unique "Kings without a kingdom" still claiming to be the sacred rulers of Orissa. The problems with which the "secular" Government of Orissa was faced were not unlike to those experienced by its Muslim, Hindu and Christian predecessors. As "the administration under the Superintendent has further deteriorated and a situation has arisen rendering it expedient to reorganise the scheme of management of the affairs of the Temple and its properties and provide better administration and governance", ${ }^{71}$ the government very soon passed a series of acts which thoroughly changed the whole system.

Regarding the main subject of this article-the peculiar relationship of the political powers of Orissa with the Jagannatha cult-three points emerge. First, the

68 Dowdeswell, Secr. to Govt., to Oswald, Superint. Trib. Mahals, 10 Feb. 1814, Board of Revenue, Cuttack, Judicial Dept.

69 N. Patnaik, "The Recent Kings of Puri: a Study of Secularization", Journal of the Indian Anthropological Society, V, nos $1 / 2(1970)$, pp. 87-114.

$70 \mathrm{~A}$ Memorial to His Excellency the Crown Representative the Viceroy and Governor-General of India in Council. By Raja
Ramachandra Deb, Raja of Khurda and the hereditary Superintendent of the Jagannatha Temple in the District of Puri (Orissa). Puri, 1947 (the exact date is not mentioned). The author is indebted to Shri Jitamitra Singh Deo of Khariar for providing a copy of the Memorial.

71 Preface to the Shri Jagannath Temple Act, 1954 (Orissa Act No. XI of 1955). 
Government of Orissa took over the administration of the Puri temple through the new Shri Jagannatha Temple Act, 1954 (Orissa Act XI of 1955). It is clearly stated that all former laws and regulations regarding the temple superintendence of "the Raja of Khurda or the Raja of Puri shall cease to have any affect". A Shri Jagannatha Temple Managing Committee was constituted and its Chief Executive Officer became an Administrator, appointed by the Government of Orissa. Secondly, the Rajas of Puri lost their title of Rajas of Khurda. From their previous title as "Raja of Khurda or the Raja of Puri" the Jagannatha Temple Act only recognised their rights as Rajas of Puri. Furthermore these rights were defined in a very restrictive way: "Raja of Puri means the person on whom rests for the time being the obligation of discharging the duties of a sevak in respect of the Gajapati Maharaj Seva [service] as recorded in the Record-of-Rights." Thus the institution of the Raja of Khurda was finally abolished by the Government of Orissa even before the royal privileges and privy purses were stopped in India as a whole. The Shri Jagannatha Temple Act abolished the "wordly" rights of the Raja of Puri, both his temple Superintendence and his title of Raja of Khurda. Thirdly, the Recordof-Rights prepared under the Puri Shri Jagannatha Temple Administration Act (Orissa Act XIV of 1952), clearly approved his sacred role as performing the Gajapati Maharaj Seva. These Records give a detailed description both of the royal services (seva) and of the remuneration to be received by the Raja. His most important sevas are the ritual sweeping of the cars and several royal duties (rajaniti) which have to be performed before Lord Jagannatha.

It is significant for our theme that, at a time when these Rajas are "no longer considered godly", the "secular" Government of Orissa had to acknowledge the divine aspect of the Gajapati Maharaja Seva. The present Government of Orissa even went a step further than its predecessors and openly announced in its new Record-of-Rights: "The Raja of Puri is called Calanti Vishnu because similar honours as to the God Vishnu are shown to him when he enters the temple."72

Since the temple administration has been taken over by the Government of Orissa the situation has become similar to those we have come across under the Marathas and in the early period of British rule. Both these governments brought the management of the temple under their direct control and restricted the influence and power of the Rajas of Khurda as much as possible. At the same time they had paid a considerable amount of money for the maintenance of the temple and its cult. It was mainly due to the powerful propaganda of the Christian missionaries that this system, as introduced by the Marathas, was changed in favour of the Khurda Rajas. One reason for this similarity in the attitudes towards the Rajas of Khurda of the post-independence and pre-independence governments is doubtless the suspicion of the influence which might arise from an institutionalized link between a local territorial power and the cult of the state deity of Orissa. Immediately after the establishment of their power in Orissa both the Marathas and the British East India Company, under various pretexts, rooted out the traditional political system of Orissa based on the direct link between the dominant local raja and the Jagannatha cult. The Marathas took over the direct administration of the Jagannatha temple and the East India Company ousted the Rajas of Khurda from their ancestral territorium. Considering the tremendous influence, especially in rural 
areas, of the idea of the Gajapati as the sacred ruler of Jagannatha's empire of Orissa it is not astonishing that after independence the new Government of Orissa lost no time in reducing the political aspect of the Gajapati idea.

The Jagannatha cult always has been a crucial element in the politics of the various powers ruling over Orissa. The non-Hindu powers, the Mughals and the East India Company, tolerated and sometimes even encouraged the cult for economic and political reasons. At the same time, they considerably restricted the power and rights of the Khurda Rajas, without, however, the intention of upsetting the whole political system, the functioning of which was essential for their rule in Orissa. The Indian powers, the Marathas and the present Government of Orissa, however, were not willing to accept the existence of any "sacred ruler" of Orissa who would claim a spiritual superiority over them. But as Hindu governments they were in a position to take over the direct control of the temple administration without endangering their own position. On the contrary, a well organized car festival under their "direct rule" in Puri would spread the fame of these new Hindu rulers to the hinterland of Puri. It is, therefore, not astonishing that the Marathas, the East India Company during the first decades of their rule in Orissa and the present Government have been willing to subsidize heavily the State Cult of Orissa. 